\title{
Mathematical modeling of bovine brucellosis control using the RB51 vaccine
}

\section{Modelagem matemática do controle da brucelose bovina com a utilização da vacina RB51}

\author{
Vanessa Aparecida Feijó de Souza ${ }^{1}$; José Soares Ferreira Neto²; \\ Marcos Amaku²; Ricardo Augusto Dias ${ }^{2}$; \\ Evelise Oliveira Telles²; José Henrique Hildebrand Grisi-Filho²; \\ Marcos Bryan Heinemann ${ }^{2}$; Fernando Ferreira ${ }^{2 *}$
}

\begin{abstract}
The Brazilian Ministry of Agriculture, Livestock and Food Supply established the National Program for Control and Eradication of Brucellosis and Tuberculosis (PNCEBT) in 2001. One of the main strategies adopted by the program is the mandatory vaccination of heifers between three and eight months of age with the B19 strain. In 2007, Brazil allowed the use of RB51 vaccine in bovine females over 8 months of age as an option for the producer, but kept the B19 strain as a mandatory vaccine. This decision is based on the assumption that combining the two vaccines allows to achieve significant vaccination coverage sooner and, consequently, accelerates the fall speed of prevalence. Thus, this study aimed to measure the impact of the combined use of these two vaccines in reducing the prevalence, using as a tool the mathematical modeling. It was concluded that vaccination by RB51, if adopted as a complement to vaccination by B19, mean decrease in the prevalence of bovine brucellosis in less time.
\end{abstract}

Key words: Bovine brucellosis. Thematical modeling. Vaccine. B19. RB51.

\section{Resumo}

O Ministério da Agricultura Pecuária e Abastecimento brasileiro instituiu o Programa Nacional de Controle e Erradicação da Brucelose e da Tuberculose Animal em 2001. Uma das principais medidas adotadas pelo programa é a vacinação obrigatória de fêmeas entre três e oito meses de idade com a cepa B19. Em 2007, o Brasil permitiu a utilização da vacina RB51 em fêmeas bovinas com mais de 8 anos de idade como uma opção para o produtor, porém manteve como vacina obrigatória a B19 em bezerras de 3 a 8 meses de idade. Essa decisão parte do princípio de que combinando as duas vacinas abrevia-se o tempo para a obtenção de coberturas vacinais expressivas na população de fêmeas em idade de procriar e, consequentemente, acelera-se a velocidade de queda da prevalência. Assim, o presente estudo objetivou medir o impacto do uso combinado dessas duas vacinas na redução da prevalência, utilizando como instrumento a modelagem matemática. Concluiu-se que a vacinação pela RB51, se adotada de forma complementar à vacinação pela B19, significaria queda da prevalência da brucelose bovina em menor intervalo de tempo.

Palavras-chave: Brucelose bovina. Modelagem matemática. Vacina. B19. RB51

\footnotetext{
Discente, Faculdade de Medicina Veterinária e Zootecnia, FMU, São Paulo, SP, Brasil. E-mail: vanessa.feijo@fmu.br

2 Profs., Faculdade de Medicina Veterinária e Zootecnia, USP, São Paulo, SP, Brasil. E-mail: grisi@vps.fmvz.usp.br; fernando@ vps.fmvz.usp.br; amaku@vps.fmvz.usp.br; dias@vps.fmvz.usp.br; evelise@vps.fmvz.usp.br; marcosbryan@usp.br; jsoares@ vps.fmvz.usp.br

* Author for correspondence
} 


\section{Introduction}

Bovine brucellosis is a disease for which most countries have official control programs in place as it is considered a zoonosis and it causes economic losses to producers (ACHA; SZYFRES, 2001; LAGE et al., 2006; PAULIN; FERREIRA NETO, 2003).

In 2001, the Brazilian Ministry of Agriculture, Livestock and Food Supply (MAPA) introduced the National Program for Control and Eradication of Brucellosis and Tuberculosis (PNCEBT) in order to reduce the impact of brucellosis and tuberculosis on human and animal health, and to improve the competitiveness of the Brazilian cattle industry (LAGE et al., 2006).

Since the introduction of the PNCEBT, MAPA's Collaborating Centre for Animal Health, located at the School of Veterinary Medicine and Animal Science, at the University of São Paulo, along with MAPA itself and the official veterinary services of the states, studied the epidemiological situation of these two infections in order to generate high-quality data to best develop disease control strategies and management processes.

Studies on bovine brucellosis were conducted in 18 states, housing $85 \%$ of the total Brazilian bovine stock, and the prevalence of herds infected with bovine brucellosis had varied from $0.32 \%$ to $41.5 \%$ in the states of Santa Catarina and Mato Grosso do Sul, respectively (ALMEIDA et al., 2016; ALVES et al., 2009; AZEVEDO et al., 2009; BORBA et al., 2013; CHATE et al., 2009; CLEMENTINO et al., 2016; DIAS et al., 2009a, 2009b; GONÇALVES et al., 2009a, 2009b; KLEIN-GUNNEWIEK et al., 2009; MARVULO et al., 2009; NEGREIROS et al., 2009; OGATA et al., 2009; ROCHA et al., 2009; SIKUSAWA et al., 2009; SILVA et al., 2009; VILLAR et al., 2009).

In light of these findings, one of the key strategies recommended by PNCEBT to reduce the prevalence of bovine and bubaline brucellosis, was to require farming properties to undergo compulsory B19 vaccination of heifers aged between 3 and 8 months (LAGE et al., 2006). The B19 vaccine is used worldwide because it is considered safe, immunogenic and easy to make. However, administration of the vaccine has its disadvantages which includes the risk of inducing infection in humans, the possibility of induced abortion in pregnant cows and providing a false positive result in serological tests, which can be avoided by restricting the vaccination to cows aged between 3 and 8 months, and by performing serological tests only after 24 months of age (BECKETT; MC DIARMID, 1985; MEYER, 1985; MONTES et al., 1986; NICOLETTI, 1990).

After about ten years from the completion of the first studies on the prevalence of brucellosis, a second study was conducted to investigate the effectiveness of the vaccination programs in the states of São Paulo, Minas Gerais, Espírito Santo, Rondônia, Mato Grosso, Mato Grosso do Sul and Rio Grande do Sul. However, a decrease in the prevalence of infected herds was found only in Mato Grosso, Mato Grosso do Sul, Minas Gerais and Rondônia (BARDDAL et al., 2016; DIAS et al., 2016; ANZAI et al., 2016; INLAMEA et al., 2016; LEAL FILHO et al., 2016; OLIVEIRA et al., 2016; SILVA et al., 2016). The state of Santa Catarina, which had exhibited the lowest prevalence of infected herds and animals, had prohibited the vaccination and had, instead, implemented eradication strategies. Nonetheless, they indicated, in a second study, that there epidemiological situation did not change (BAUMGARTEN et al., 2016).

The search for vaccines that do not interfere with diagnostic tests, and that could be used in adult cows, led to the development of a vaccine derived from the rough strain RB51 (SCHURIG et al., 1991). A rough strain lacks the membrane O-chain component, and as a result, does not stimulate an O-chain-specific immunogenic response that would otherwise allow for antibody detection via 
serological tests used in the diagnosis of bovine brucellosis (JIMÉNEZ DE BAGÜÉS et al., 1994; SCHURIG et al., 1991; TOBIAS et al., 1993; OLSEN et al., 2003; STEVENS et al., 1994, 1995).

In 2007, Brazil allowed ranchers to use the RB51 vaccine in bovine females over 8 months of age, however, the vaccination of calves aged from 3 to 8 months with the B19 strain remained compulsory (BRASIL, 2007). The underpinning assumption was that the combination of the two vaccines had the effect of potentiating and therefore, shortening the time needed to obtain significant immunization coverage for cows of childbearing age, and consequently, reduce the prevalence of the disease.

Thus, given the importance of the vaccination against brucellosis to PNCEBT, this study aimed at measuring the impact of the combined use of these two vaccines in reducing the prevalence of the disease, through mathematical modeling, similar to that used by Amaku et al. (2009) for the B19 vaccine.

\section{Material and Methods}

\section{Mathematical modeling}

The mathematical model was based on the model proposed by Amaku et al. (2009). In this model, the population of cows was grouped into seven compartments: susceptible (S), primiparous latent carriers (L1), primiparous infectious cows (I1), multiparous latent carriers (L2) multiparous infectious cows (I2), those vaccinated with the B19 strain (V1) and those vaccinated with the RB51 strain (V2). The compartment diagram shown in Figure 1 illustrates the dynamics of bovine brucellosis between the compartments.

Figure 1. Compartment diagram illustrating the dynamics of bovine brucellosis according to the proposed model.
The following set of differential equations was used for the mathematical representation of this dynamic:

$(1-p) \eta(t)\left\{S+V_{1}+V_{2}+(1-\rho)\left[(1-\alpha) L_{1}+L_{2}\right]\right\}-(\mu+r) S-\lambda(t) S$

$\frac{d L_{1}}{d t}=\lambda(t) S+\rho \eta(t)\left[(1-\alpha) L_{1}+L_{2}\right]-(\gamma+\mu) L_{1}$

$\frac{d I_{1}}{d t}=\gamma L_{1}-(\delta+\alpha) I_{1}$

$\frac{d L_{2}}{d t}=\delta\left(I_{1}+I_{2}\right)-(\gamma+\mu) L_{2}$

$\frac{d I_{2}}{d t}=\gamma L_{2}-(\delta+\mu) I_{2}$

$\left.\frac{d V_{1}}{d t}=\rho \eta(t)\left\{S+V_{1}+V_{2}+(1-\rho)[1-\alpha) L_{1}+L_{2}\right]\right\}-\mu V_{1}$

$\frac{d V_{2}}{d t}=r S-\mu V_{2}$

The force of infection was defined by $\lambda(t)=$ $\beta\left(I_{1}+I_{2}\right)$, where $\beta$ is the transmission coefficient expressed by the number of potentially infectious contacts, per capita, per unit of time. The extent of vaccination coverage conferred by the $\mathrm{B} 19$ strain is defined by $p$. For simulating the model, $p$ was set to $80 \%$.

The vaccination coverage rate of RB51 was obtained from the following equation, where $p_{R B 51}$ is the annual coverage rate of animals vaccinated with RB51:

$$
r=I_{n}\left(1-p_{R B 51}\right)
$$

Mortality rate, $\mu$, was estimated assuming that the average life expectancy of cows was seven years. In contrast, the replacement rate was expressed by $\eta$. A population of constant size requires equilibrium between these aforementioned parameters, such that the replacement rate must be equal to: 


$$
\eta(t)=\frac{\mu N}{S+V_{1}+V_{2}+(1-\alpha) L_{1}+L_{2}}
$$

where $N=S+L_{1}+L_{2}+I_{1}+I_{2}+V_{1}+V_{2}$ and refers to the proportion of primiparous cows that have miscarried, estimated at $80 \%$ (PAULIN; FERREIRA NETO, 2003).

A fraction, $\rho$, of the calves born to the infected cows became latent carriers. This fraction was estimated to be 3\% (PAULIN; FERREIRA NETO, 2003). Female latent carriers became infectious at a rate, $\gamma$, defined from the calving interval. To calculate the parameter, a calving interval of 20 months was adopted for infected cows (FARIA, 1984).

The period in which the cows remained infectious was estimated to be 30 days. The recurrence rate at which these cows became latent carriers was defined by $\delta$, which was equivalent to the inverse of the infectious period.

The model was used to simulate the dynamics of the disease in each of the states where the prevalence was found to be higher than $1 \%$ in the initial surveys conducted by PNCEBT. These states were: Espírito Santo, Goiás, Maranhão, Mato Grosso, Rio de Janeiro, Rondônia, São Paulo, Sergipe and Tocantins (AZEVEDO et al., 2009; BORBA et al., 2013; DIAS et al., 2009; KLEIN-GUNNEWIEK et al., 2009; NEGREIROS et al., 2009; OGATA et al., 2009; ROCHA et al., 2009; SILVA et al., 2009; VILLAR et al., 2009).

For the initial conditions of the simulation, it was considered, from the total number of cows over 24 months of age in each state, that the fraction corresponding to the seroprevalence found in the PNCEBT studies would be categorized to the latent L2 compartment. The remaining animals were considered susceptible and were therefore allocated to the $\mathrm{S}$ compartment. The other compartments did not contain any individuals at the beginning of the simulations.

Despite the arbitrary initial conditions, a comparative assessment between the associative effects of the RB51 and B19 vaccines was possible.

The value of $\beta$ was adjusted for each state to yield the prevalence found in this study.

The simulations were performed with the aid of package deSolve (SOETAERT et al., 2010) using the Fourth Order-Runge-Kutta method from the $\mathrm{R}$ software (R CORE TEAM, 2015).

\section{Results, Discussion and Conclusion}

Simulations were run for each state in order to assess the magnitude of the effect produced by the combination of the RB51 and B19 vaccines for the control of bovine brucellosis.

The scenarios that were simulated always included the B19 vaccination into consideration as its efficacy has been proven. Additionally, the PNCEBT guidelines do not advocate for its replacement with the RB51 strain.

Thus, all simulations involved the assumption of an $80 \%$ vaccination coverage rate for the B19 strain for heifers aged between 3 and 8 months, whereby in each scenario, the vaccination coverage rate for the rough strain RB51 varied as follows: $0 \%, 10 \%$, $40 \%$ and $80 \%$ of animals that were unvaccinated with the B19 strain. The results of the simulation are shown in Figure 2.

Figure 2. Graphs indicating the simulation of the bovine 
brucellosis prevalence in the Brazilian States as a result of vaccination of $80 \%$ of the heifers with B19, associated with immunization with RB 51 of 10, 40 and $80 \%$ of non-vaccinated females with B19.
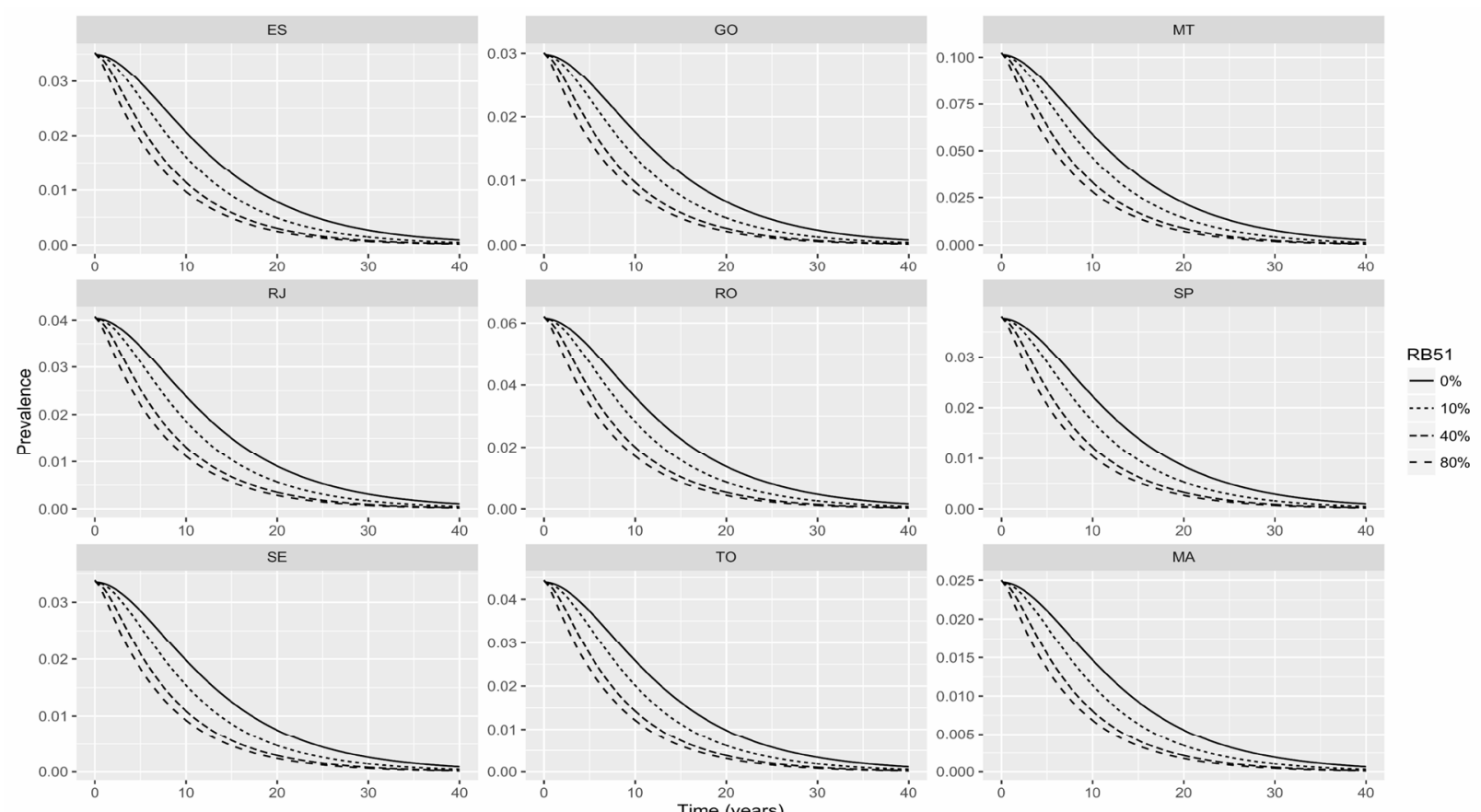

as the basis for comparison between each scenario. This value was chosen as it was the same value that was determined by the state of Minas Gerais, which implemented a well structured vaccination program with B19 strain for the control of the disease (OLIVEIRA et al., 2016).

Through an analysis of the graphs shown in Figure 2 and Table 1, it is possible to conclude that in all of the states that were evaluated, that the vaccination of adult cows with the B19 strain and adjuvant RB51 strain, had considerably reduced the time required to lower the prevalence of the disease to $1 \%$, particularly when this combination was applied to the scenarios where $40 \%$ and $80 \%$ of the animals comprised the susceptible population.

Table 1. Estimated time (years) to lower the prevalence to $1 \%$ in the different states, considering vaccination of 
$80 \%$ of the heifers with B19, associated with immunization with RB 51 of 10,40 and $80 \%$ of non-vaccinated females with B19.

\begin{tabular}{lccccc}
\hline \multirow{2}{*}{ States } & \multirow{2}{*}{$\begin{array}{c}\text { Initial } \\
\text { prevalence }\end{array}$} & B19 only & $\begin{array}{c}\text { B19 and RB51 } \\
(\mathbf{1 0 \% )}\end{array}$ & $\begin{array}{c}\text { B19 and RB51 } \\
\mathbf{( 4 0 \% )}\end{array}$ & B19 and RB51 (80\%) \\
\cline { 3 - 6 } & & 17.6 & 14.0 & 10.9 & 9.7 \\
Espírito Santo & $3.53 \%$ & 12.7 & 9.7 & 8.5 \\
Goiás & $3.01 \%$ & 16.0 & 11.2 & 8.3 & 7.2 \\
Maranhão & $2.50 \%$ & 14.2 & 22.9 & 19.0 & 17.5 \\
Mato Grosso & $10.25 \%$ & 27.5 & 15.3 & 12.0 & 10.8 \\
Rio de Janeiro & $4.08 \%$ & 19.9 & 18.7 & 15.2 & 13.9 \\
Rondônia & $6.22 \%$ & 22.9 & 14.7 & 11.5 & 10.3 \\
São Paulo & $3.81 \%$ & 18.3 & 13.7 & 10.6 & 9.4 \\
Sergipe & $3.38 \%$ & 17.2 & 15.9 & 12.6 & 11.4 \\
Tocantins & $4.43 \%$ & 19.8 & & & \\
\hline
\end{tabular}

In the scenario with an $80 \%$ vaccination coverage rate involving the use of the RB51 strain in combination with the B19 strain, the percentage reduction in the time required to lower the prevalence to $1 \%$ had varied with respect to the scenario involving the exclusive use of the B19 strain, from $36 \%$ to $49 \%$, in extreme cases found in the states of Mato Grosso and Maranhão, respectively.

Intriguingly, the difference in time required to achieve a prevalence of $1 \%$ between the scenarios involving RB51 vaccination coverage rates of $40 \%$ and $80 \%$, was only a year or two. Nonetheless, in the $40 \%$ RB51 vaccination coverage scenario, there vaccinated with RB51, i.e., delay of one or two years to reach the same prevalence is compensated by $15 \%$ reduction of the vaccinated animals (Table 2).

Subsequent studies should analyze which strategy is the most economically viable. Nevertheless, it is possible to conclude that vaccination with rough strain RB51, complementarily to the B19 strain, would contribute towards implementing the guidelines proposed by PNCEBT more quickly. is a reduction of $15 \%$ of the number of animals

Table 2. Total number of animals vaccinated with the RB51 strain arranged according to the factors of different vaccination coverage rates, and states, required for a prevalence of $1 \%$ for bovine brucellosis.

\begin{tabular}{lrrr}
\hline \multirow{2}{*}{ States } & \multicolumn{3}{c}{ Number of animals vaccinated with RB51 } \\
\cline { 2 - 4 } & $\mathbf{1 0 \%}$ Immunization & $\mathbf{4 0 \%}$ Immunization & $\mathbf{8 0 \%}$ Immunization \\
\hline Espírito Santo & 392,097 & 732,392 & 859,808 \\
Goiás & $4,130,984$ & $7,787,032$ & $9,142,381$ \\
Maranhão & $1,127,649$ & $2,156,426$ & $2,541,575$ \\
Mato Grosso & $4,899,907$ & $8,988,640$ & $10,557,806$ \\
Rio de Janeiro & 491,126 & 909,232 & $1,067,809$ \\
Rondônia & $2,040,025$ & $3,750,213$ & $4,404,337$ \\
São Paulo & $2,567,059$ & $4,771,408$ & $5,602,371$ \\
Sergipe & 169,312 & 316,652 & 371,721 \\
Tocantins & $1,634,091$ & $3,021,791$ & $3,549,954$ \\
\hline
\end{tabular}

\section{Acknowledgements}


The authors acknowledge the logistical and financial support from MAPA, IMA, CNPq and FAPESP.

\section{References}

ACHA, P. N.; SZYFRES, B. Zoonosis y enfermidades transmissibles comunes al hombre y los animales: bacteriosis y micosis. $3^{\text {th }}$ ed. Washington: OPS, 2001. v. $1,398 \mathrm{p}$.

ALMEIDA, E. C.; FREITAS, A. A.; PONTUAL, K. A. Q.; SOUZA, M. M. A.; AMAKU, M.; DIAS, R. A.; FERREIRA, F.; TELLES, E. O.; HEINEMANN, M. B.; GONÇALVES, V. S. P.; EVÊNCIO NETO, J.; MARVULO, M. F. V.; GRISI-FILHO, J. H. H.; FERREIRA NETO, J. S.; SILVA, J. C. R. Prevalence and associated risk factors for bovine brucellosis in the state of Pernambuco, Brazil. Semina: Ciências Agrárias, Londrina, v. 37, n. 5, p. 3413-3424, 2016. Suplemento 2.

ALVES, A. J. S.; GONÇALVES, V. P. S.; FIGUEIREDO, V. C. F.; LOBO, J. R.; BAHIENSE, L.; AMAKU, M.; FERNANDO, F.; FERREIRA NETO, J. S.; DIAS, R. A. Situação epidemiológica da brucelose bovina no Estado da Bahia. Arquivo Brasileiro de Medicina Veterinária e Zootecnia, Belo Horizonte, v. 61, p. 6-13, 2009. Suplemento 1.

AMAKU, M.; DIAS, R. A.; FERREIRA NETO, J. S.; FERREIRA, F. Modelagem matemática do controle de brucelose bovina por vacinação. Arquivo Brasileiro de Medicina Veterinária e Zootecnia, Belo Horizonte, v. 61, p. 135-141, 2009. Suplemento 1.

ANZAI, E. K.; COSTA, D.; SAID, A. L. P. R.; GRISI-FILHO, J. H. H.; AMAKU, M.; DIAS, R. A.; FERREIRA, F.; GALVIS, J. O. A.; GONÇALVES, V. S. P.; HEINEMANN, M. B.; TELLES, E. O.; FERREIRA NETO, J. S. An update on the epidemiological situation of bovine brucellosis in the state of Espírito Santo, Brazil. Semina: Ciências Agrárias, Londrina, v. 37, n. 5, p. 3437-3448, 2016. Suplemento 2.

AZEVEDO, S. S.; FERREIRA NETO, J. S.; DIAS, R. A.; FERREIRA, F.; AMAKU, M.; FIGUEIREDO, V. C. F.; LOBO, J. R.; GONÇALVES, V. S. P.; SOUZA, A. C.; VASCONCELLOS, S. A. Situação epidemiológica da brucelose bovina no Estado do Espírito Santo. Arquivo Brasileiro de Medicina Veterinária e Zootecnia, Belo Horizonte, v. 61, p. 19-26, 2009. Suplemento 1.
BARDDAL, J. E. I.; SANTOS, J. C. Q.; LOPES, I. F.; FERREIRA NETO, J. S.; FERREIRA, F.; AMAKU, M.; DIAS, R. A.; TELLES, E. O.; GRISI-FILHO, J. H. H.; HEINEMANN, M. B.; GONÇALVES, V. S. P.; AGUIAR, D. M. Effect of vaccination in lowering the prevalence of bovine brucellosis in the state of Mato Grosso, Brazil. Semina: Ciências Agrárias, Londrina, v. 37, n. 5, p. 3479-3492, 2016. Suplemento 2.

BAUMGARTEN, K. D.; VELOSO, F. P.; GRISI-FILHO, J. H. H.; FERREIRA, F.; AMAKU, M.; DIAS, R. A.; TELLES, E. O.; HEINEMANN, M. B.; GONÇALVES, V. S. FERREIRA NETO, J. S. Prevalence and risk factors for bovine brucellosis in the State of Santa Catarina, Brazil. Semina: Ciências Agrárias, Londrina, v. 37, n. 5, p. 3413-3424, 2016. Suplemento 2.

BECKETT, F. W.; MC DIARMID, S. C. The effect of reduced-dose Brucella abortus strain 19 vaccinations in accredited dairy herds. British Veterinary Journal, v. 141, n. 5, p. 507-514, 1985.

BORBA, M. R.; STEVENSON, M. A.; GONÇALVES, V. S. P.; FERREIRA NETO, J. S.; FERREIRA, F.; AMAKU, M.; TELLES, E. O.; SANTANA, S. S.; FERREIRA, J. C. A.; LÔBO, J. R.; FIGUEIREDO, V. C. F.; DIAS, R. A. Prevalence and risk-mapping of bovine brucellosis in Maranhão State, Brazil. Preventive Veterinary Medicine, v. 110, n. 2, p. 169-176, 2013.

BRASIL. Ministério da Agricultura, Pecuária e Abastecimento. Secretaria de Defesa Agropecuária. Instrução Normativa $\mathrm{n}^{\circ}$ 33, de 24 de agosto de 2007. Diário Oficial [da] União, Brasília, 24 ago. 2007. Seção 1, p. 6.

CHATE, S. C.; DIAS, R. A.; AMAKU, M.; FERREIRA, F.; MORAES, G. M.; COSTA NETO, A. A.; MONTEIRO, L. A. R. C.; LOBO, J. R.; FIGUEIREDO, V. C. F.; GONÇALVES, V. S. P.; FERREIRA NETO, J. S. Situação epidemiológica da brucelose bovina no Estado do Mato Grosso do Sul. Arquivo Brasileiro de Medicina Veterinária e Zootecnia, Belo Horizonte, v. 61, p. 46-55, 2009. Suplemento 1.

CLEMENTINO, I. J.; DIAS, R. A.; AMAKU, M.; FERREIRA, F.; TELLES, E. O.; HEINEMANN, M. B.; GONÇALVES, V. S. P.; GRISI-FILHO, J. H. H.; FERREIRA NETO, J. S.; ALVES, C. J.; SANTOS, C. S. A. B.; AZEVEDO, S. S. Epidemiological situation of bovine brucellosis in the state of Paraiba, Brazil. Semina: Ciências Agrárias, Londrina, v. 37, n. 5, p. 3403-3412, 2016. Suplemento 2. 
DIAS, J. A.; MÜLLER, E. E.; DIAS, R. A.; FREITAS, J. C.; AMAKU, M.; FERREIRA, F.; SILVA, M. C. P.; LOBO, J. R.; FIGUEIREDO, V. C. F.; GONÇALVES, V. S. P.; FERREIRA, NETO, J. S. Situação epidemiológica da brucelose bovina no Estado do Paraná. Arquivo Brasileiro de Medicina Veterinária e Zootecnia, Belo Horizonte, v. 61, p. 66-76, 2009a. Suplemento 1.

DIAS, R. A.; BELCHIOR, A. P. C.; FERREIRA, R. S.; GONÇALVES, R. C.; BARÃO. R. S. C.; SOUSA, P. R.; SANTOS, A. M. A.; AMAKU, M.; FERREIRA, F.; TELLES, E. O.; GRISI-FILHO, J. H. H.; HEINEMANN, M. B.; GONÇALVES, V. S. P.; FERREIRA NETO, J. S. Controlling bovine brucellosis in the State of São Paulo, Brazil: results of ten years of vaccination program. Semina: Ciências Agrárias, Londrina, v. 37, n. 5, p. 3505-3518, 2016a. Suplemento 2.

DIAS, R. A.; GONÇALVES, V. S. P.; FIGUEIREDO, V. C. F.; LOBO, J. R.; LIMA, Z. M. B.; PAULIN, L. M. S.; GUNNEWIEK, M. F. K.; AMAKU, M.; FERREIRA NETO, J. S.; FERREIRA, F. Situação epidemiológica da brucelose bovina no Estado de São Paulo. Arquivo Brasileiro de Medicina Veterinária e Zootecnia, Belo Horizonte, v. 61, p. 118-125, 2009b. Suplemento 1.

FARIA, J. F. Situação da brucelose no Brasil. Comunicações Científicas da Faculdade de Medicina Veterinária e Zootecnia, São Paulo, v. 8, n. 2, p. 161-175, 1984.

GONÇALVES, V. S. P.; DELPHINO, M. K. V. C.; DIAS, R. A.; FERREIRA, F.; AMAKU, M.; FERREIRA NETO, J. S.; PORTO, T. B.; ALVES, C. M.; FIGUEIREDO, V. C. F.; LOBO, J. R. Situação epidemiológica da brucelose bovina no Estado de Minas Gerais. Arquivo Brasileiro de Medicina Veterinária e Zootecnia, Belo Horizonte, v. 61, p. 35-45, 2009a. Suplemento 1.

GONÇALVES, V. S. P.; RIBEIRO, L. A.; CALDAS, R. A.; FRANCISCO, P. F. C.; DIAS, R. A.; FERREIRA, F.; AMAKU, M.; FERREIRA NETO, J. S.; FIGUEIREDO, V. C. F.; LOBO, J. R.; BORGES, J. R. J. Situação epidemiológica da brucelose bovina no Distrito Federal. Arquivo Brasileiro de Medicina Veterinária e Zootecnia, Belo Horizonte, v. 61, p. 14-18, 2009b. Suplemento 1.

INLAMEA, O. F.; ROCHA, A. B.; FERREIRA, F.; GRISI-FILHO, J. H. H.; HEINEMANN, M. B.; DIAS, R. A.; TELLES, E. O.; GONÇALVES, V. S. P.; AMAKU, M.; FERREIRA NETO, J. S. Effect of vaccination in lowering bovine brucellosis in the state of Rondônia, Brazil. Semina: Ciências Agrárias, Londrina, v. 37, n. 5, p. 3493-3506, 2016. Suplemento 2.

JIMÉNEZ DE BAGÜÉS, M. P.; ELZER, P. H.; JONES, S. M.; BLASCO, J. M.; ENRIGHT, F. M.; SCHURIG, G. G.; WINTER, A. J. Vaccination with Brucella abortus rough mutant $\mathrm{RB} 51$ protects $\mathrm{BALB} / \mathrm{c}$ mice against virulent strains of Brucella abortus, Brucella melitensis, and Brucella ovis. Infection and Immunity, v. 62, p. 49904996, 1994.

KLEIN-GUNNEWIEK, M. F. C.; AMAKU, M.; DIAS, R. A.; FERREIRA, F.; GITTI, C. B.; PEREIRA, L. A.; FIGUEIREDO, V. C. F.; LOBO, J. R.; GONÇALVES, V. S. P.; FERREIRA NETO, J. S. Situação epidemiológica da brucelose bovina no Estado do Rio de Janeiro. Arquivo Brasileiro de Medicina Veterinária e Zootecnia, Belo Horizonte, v. 61, p. 77-84, 2009. Suplemento 1.

LAGE, A. P.; ROXO, E.; MÜLlER, E.; POESTER, F.; CAVALlÉRO, J. C. M.; FERREIRA NETO, J. S.; MOTA, P. M. P. C.; GONÇALVES, V. S. P. Programa nacional de controle e erradicação da brucelose e tuberculose animal (PNCEBT). Brasília: Ministério da Agricultura, Pecuária e Abastecimento, 2006. 184 p. (Manual técnico).

LEAL FILHO, J. M.; BOTTENE, I. F. N.; MONTEIRO, L. A. R. C.; PELlEGRIN, A. O.; GONÇALVES, V. S. P.; FERREIRA, F.; DIAS, R. A.; AMAKU, M.; TELLES, E. O.; GRISI-FILHO, J. H. H.; HEINEMANN, M. B.; FERREIRA NETO, J. S. Control of bovine brucellosis from 1998 to 2009 in the state of Mato Grosso do Sul, Brazil. Semina: Ciências Agrárias, Londrina, v. 37, n. 5, p. 3467-3478, 2016. Suplemento 2.

MARVULO, M. F. V.; FERREIRA, F.; DIAS, R. A.; AMAKU, M.; GROFF, A. C. M.; GONÇALVES, V. S. P.; FIGUEIREDO, V. C. F.; LOBO, J. R.; FERREIRA, NETO J. S. Situação epidemiológica da brucelose bovina no Estado do Rio Grande do Sul. Arquivo Brasileiro de Medicina Veterinária e Zootecnia, Belo Horizonte, v. 61, p. 93-102, 2009. Suplemento 1.

MEYER, M. E. Characterization of Brucella abortus strain 19 isolated from human and bovine tissues and fluids. American Journal of Veterinary Research, v. 46, n. 4, p. 902-904, 1985.

MONTES, J.; RODRIGUEZ, M. A.; MARTIN, T.; MARTIN F. Laboratory-acquired meningitis caused by Brucella abortus strain 19. Journal of Infectious Disease, v. 154, n. 4, p. 915-916, 1986.

NEGREIROS, R. L.; DIAS, R. A.; FERREIRA, F.; FERREIRA NETO, J. S.; GONÇALVES, V. S. P.; SILVA, M. C. P.; FIGUEIREDO, V. C. F.; LOBO, J. R.; FREITAS, J.; AMAKU, M. Situação epidemiológica da brucelose bovina no Estado do Mato Grosso. Arquivo Brasileiro de Medicina Veterinária e Zootecnia, Belo Horizonte, v. 61, p. 56-65, 2009. Suplemento 1.

NICOLETTI, P. Vaccination. In: NIELSEN, K; DUNCAN, J. R. Animal brucellosis. Boca Raton: CRC Press, 1990. p. 284-299. 
OGATA, R. A.; GONÇALVES, V. S. P.; FIGUEIREDO, V. C. F.; LOBO, J. R.; RODRIGUES, A. L.; AMAKU, M.; FERREIRA, F.; FERREIRA NETO, J. S.; DIAS, R. A. Situação epidemiológica da brucelose bovina no Estado do Tocantins. Arquivo Brasileiro de Medicina Veterinária e Zootecnia, Belo Horizonte, v. 61, p. 126134, 2009. Suplemento 1.

OLIVEIRA, L. F.; DORNELES, E. M. S.; MOTA, A. L. A. A.; GONÇALVES, V. S. P.; FERREIRA NETO, J. S.; FERREIRA, F.; DIAS, R. A.; TELLES, E. O.; GRISIFILHO, J. H. H.; HEINEMANN, M. B.; AMAKU, M.; LAGE, A. P. Seroprevalence and risk factors for bovine brucellosis in the State of Minas Gerais, Brazil. Semina: Ciências Agrárias, Londrina, v. 37, n. 5, p. 3449-3446, 2016. Suplemento 2.

OLSEN, S. C.; JENSEN, A. E.; STOFFREGEN, W. C.; PALMER, M. V. Efficacy of calfhood vaccination with Brucella abortus strain RB51 in protecting bison against brucellosis. Research in Veterinary Science, Oxford, v. 74, n. 1, p. 17-22, 2003.

PAULIN, L. M.; FERREIRA NETO, J. S. O. Combate à brucelose bovina: situação brasileira. Jaboticabal: Funep, 2003. $154 \mathrm{p}$.

$\mathrm{R}$ CORE TEAM - R: a language and environment for statistical computing. R Foundation for Statistical Computing. Vienna: Austria, 2015. Available at: $<$ https:// www. R-project. org/>. Accessed at: 05 july. 2016.

ROCHA, W. V.; GONÇALVES, V. S. P.; COELHO, C. G. N. F. L.; BRITO, W. M. E. D.; DIAS, R. A.; DELPHINO, M. K. V. C.; FERREIRA, F.; AMAKU, M.; FERREIRA NETO, J. S.; FIGUEIREDO, V. C. F.; LOBO, J. R.; BRITO, L. A. B. Situação epidemiológica da brucelose bovina no Estado de Goiás. Arquivo Brasileiro de Medicina Veterinária e Zootecnia, Belo Horizonte, v. 61, p. 27-34, 2009. Suplemento 1.

SCHURIG, G. G.; ROOP, R. M.; BAGCHI, T.; BOYLE, S.; BUHRMAN, D.; SRIRANGANATHAN, N. Biological properties of RB51; a stable rough strain of Brucella abortus. Veterinary Microbiology, v. 28, n. 2, p. 171-188, 1991.

SIKUSAWA, S.; AMAKU, M.; DIAS, R. A.; FERREIRA NETO, J. S.; MARTINS, C.; GONÇALVES, V. S. P.; FIGUEIREDO, V. C. F.; LOBO, J. R.; FERREIRA, F. Situação epidemiológica da brucelose bovina no Estado de Santa Catarina. Arquivo Brasileiro de Medicina Veterinária e Zootecnia, Belo Horizonte, v. 61, p. 103108, 2009. Suplemento 1.

SILVA, N. S.; GROFF, A. C. M.; VIDOR, A. C. M.; GRISI-FILHO, J. H. H.; HEINEMANN, M. B.; DIAS, R. A.; TELLES, E. O.; GONÇALVES, V. S. P.; AMAKU, M.; FERREIRA, F.; FERREIRA NETO, J. S. Epidemiological situation of bovine brucellosis after implementation of a vaccination program in Rio Grande do Sul state, Brazil. Semina: Ciências Agrárias, Londrina, v. 37, n. 5, p. 3519-3520, 2016. Suplemento 2.

SILVA, V.G. S. O.; DIAS, R.A.; FERREIRA, F.;AMAKU, M.; COSTA, E. L. S.; LOBO, J. R.; FIGUEIREDO, V. C. F.; GONÇALVES, V. S. P.; FERREIRA NETO, J. S. Situação epidemiológica da brucelose bovina no Estado de Sergipe. Arquivo Brasileiro de Medicina Veterinária e Zootecnia, Belo Horizonte, v. 61, p. 109-117, 2009. Suplemento 1.

SOETAERT, K.; PETZOLDT T.; SETZER, R. W. Solving differential equations in R: Package deSolve. Journal of Statistical Software, v. 33, n. 9, p. 1-25, 2010.

STEVENS, M. G.; HENNAGER, S. G.; OLSEN, S. C.; CHEVILLE, N. F. Serologic responses in diagnostic tests for brucellosis in cattle vaccinated with Brucella abortus 19 or RB51. Journal of Clinical Microbiology, v. 32, n. 4, p. 1065-1066, 1994.

STEVENS, M. G.; OLSEN, S. C.; CHEVILlE, N. F. Comparative analysis of immune responses in cattle vaccinated with Brucella abortus strain 19 or strain RB51. Veterinary Immunology and Immunopathology, v. 44, n. 3-4, p. 223-235, 1995.

TOBIAS, L.; CORDES, D. O.; SCHURIG, G. G. Placental pathology of the pregnant mouse inoculated with Brucella abortus strain 2308. Veterinary Pathology, v. 30, n. 2, p. 119-129, 1993.

VILLAR, K. S.; AMAKU, M.; DIAS, R. A.; FERREIRA NETO, J. S.; BENITEZ, F.; GONÇALVES, V. S. P.; FIGUEIREDO, V. C. F.; LOBO, J. R.; FERREIRA, F. Situação epidemiológica da brucelose bovina no Estado de Rondônia. Arquivo Brasileiro de Medicina Veterinária e Zootecnia, Belo Horizonte, v. 61, p. 85-92, 2009. Suplemento 1. 
